\title{
Ergonomic evaluation in a values transportation company in Venezuela
}

\author{
Escalona, Evelin ${ }^{\mathrm{a}}$; Hernández, Maylem; ${ }^{\mathrm{a}}$ Y Yanes E, Lucia ${ }^{\mathrm{a}}$; Yanes, Laura ${ }^{\mathrm{a}}$ and Yanes, Leopoldo ${ }^{\mathrm{b}}$ \\ ${ }^{a}$ Center of Workers Heath Study, Carabobo University, Venezuela \\ ${ }^{b}$ Institute of High Studies in Health, Dr. Arnoldo Gabaldon, Venezuela
}

\begin{abstract}
The objective was to analyze the work activity and identify risk factors that could account for musculoskeletal disorders in the upper extremities, shoulder and neck of workers of a transport values company in Venezuela. The methods used were: collective interview, tasks observation, evaluation of posture with RULA method and evaluation of repetitive motions with the OCRA method. Five workstations were evaluated. Main problem perceived by workers was: exposure to chemical and biological hazards when handling paper money and coins; inadequate chairs and close supervision. The postures level risk was 1 or 2 for the RULA scale. Only two workstations showed ligth and medium risk level by OCRA method. Conclusion: The factors identified that could explain the musculoskeletal changes were: wrist repetitive flexion and extension, shoulder elevation, lifting weight above shoulder height, elbow repetitive flexion and extension, neck flexion, extended work journey, work overload, high responsibility and strict supervision by a video camera.
\end{abstract}

Keywords: activity, postures, repetitive movements, transportation of values

\section{Introduction}

The analysis of work activity is considered the worker's response to the variety of conditions. In order to do their activity, employees are committed in the accomplishment of the organization production objectives, in order to do so, they must adapt their own features and capabilities depending on the demands of work (Guerin et al, 1991), therefore, the importance of their study.

The objective of this research was to analyze the work activity and to identify risk factors that could explain musculoskeletal disorders in the upper extremities, shoulder and neck of the workers of a transport values company in Venezuela.

\section{Material and methods}

Collective interviews were conducted and the DEPARIS method was applied (Malchaire, 2009), homogeneous groups. To determine areas of pain at the end of the workday body schema was used (Escalona et al., 2002). Observations were performed to analyze tasks, postures and repetitive movements of the upper limbs. The observations of the tasks were performed during a typical work week. The positions were assessed using the RULA method (McAtamney, L. and Corlett, 1993). To evaluate repetitive movements of upper limbs was used OCRA checklist (Colombini, Occhipinti, and Grieco, 2000).

\section{Results}

\subsection{Group interviews}

Group interviews were conducted on five homogeneous groups of workers in the following workstations: Vault Chief, vault Assistant, Selection of paper money, the opening of financial and commercial remittances (see Table 1). The employees participated in groups of 2 or 3 for a total of 11 workers. The average age was 32 years (range 26 to 42 years). The predominant sex was male with $72 \%$ and $27 \%$ female. In all groups homogeneous exposure to chemical and biological ${ }^{*}$ hazards perceived as unsatisfactory (red), designated as the presence of dust problems in handling paper money and invoices. In particular, the financial remittances

\footnotetext{
*Corresponding authors. evelinescalona@gmail.com. leoyanes@gmail.com
} 
group said (standing, chairs can't be adjusted and constant monitoring by the video camera, pointing to this as unsatisfactory). The work areas, the risks of accidents, repetitive psychosocial work environment and thermal environment were assessed as unsatisfactory, with the exception of financial openers' accountability group which considered the last element as satisfactory. As for the querstion; what do you like about your job? The workers agreed on the following aspects: to work overtime, the work environment, companionship and economic benefits. In relation to those things they dislike about the work: the cold in the office, the sort of safety shoes that are uncomfortable, poor ventilation and dust of the paper money.

Table 1. Summary of the work situation in homogeneous groups collective interview. Transport company values. Venezuela, 2010.

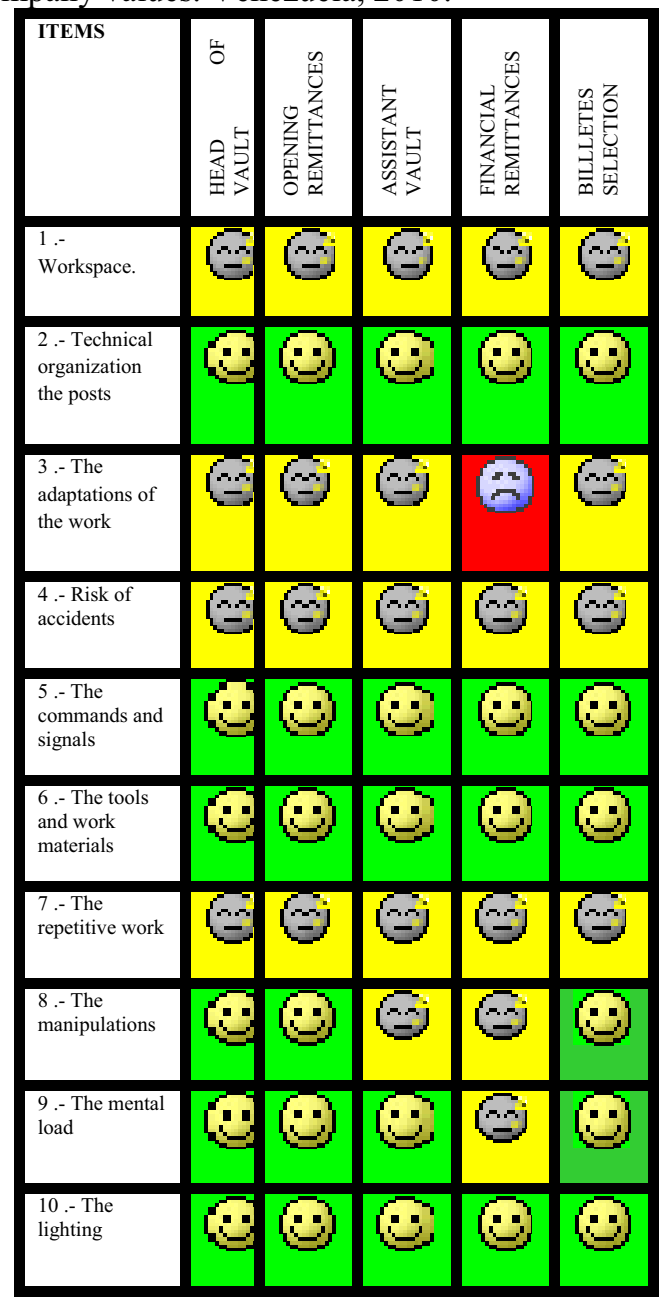

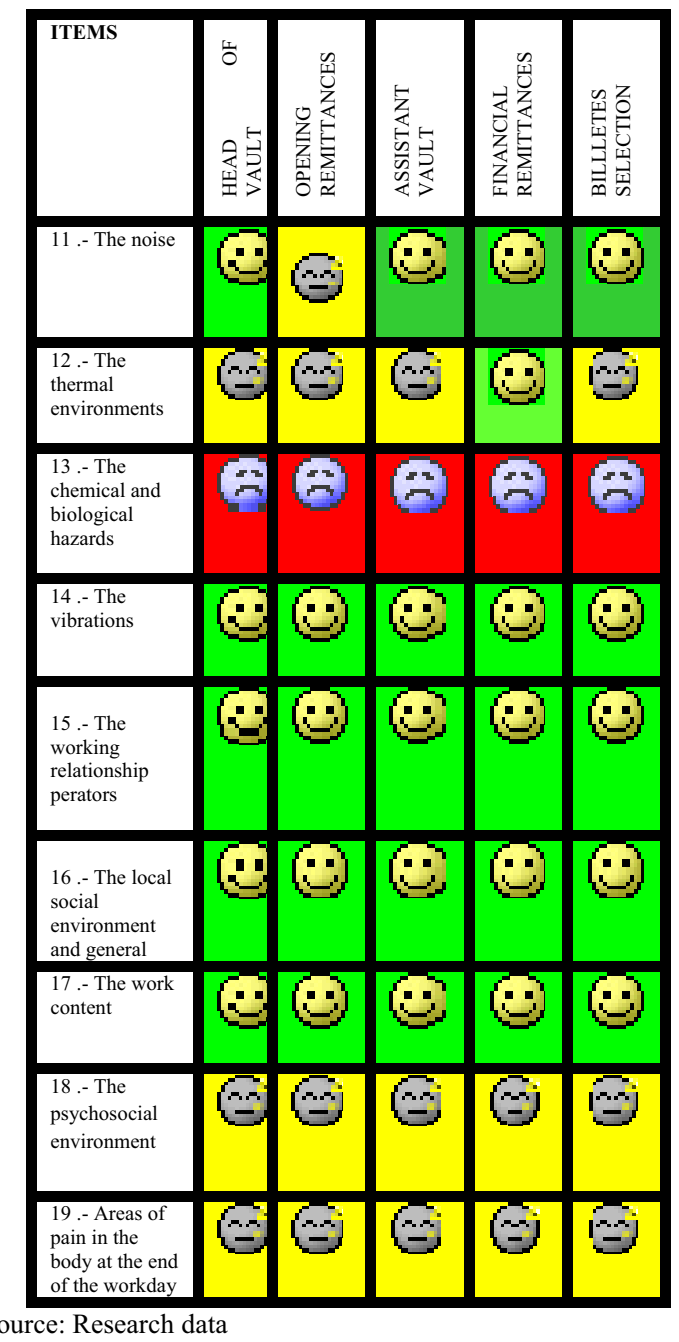

\subsection{Overview of the work activity observed}

Respecting the tasks observed, receive and prepare Commercial Remittances of currency, control the number of containers (money) and the administrative forms and introduction of information into a computerized recording system (see Table 2). The work involves a great responsibility, requiring constant attention and if mistakes are to happen, workers must pay the difference of the missing money. All activities are recorded by a video camera and workers must identify aloud the contents of the consignment. The workstations are isolated from one another and must work without communicating with other workers.

Table 2. Task observed by post. Transport company values. Venezuela, 2010. 


\begin{tabular}{|l|l|}
\hline Workstation & Main Task \\
\hline Vault Chief & Report packaging control each cashier. \\
\hline Opening remittances & Inventory control of the money received. \\
\hline Assistant vault & $\begin{array}{l}\text { Receiving remittances from different } \\
\text { commercial enterprises. }\end{array}$ \\
\hline $\begin{array}{l}\text { Paper Money } \\
\text { selection }\end{array}$ & Preparation of financial remittances \\
\hline $\begin{array}{l}\text { Financial } \\
\text { remittances }\end{array}$ & $\begin{array}{l}\text { Select tickets in good condition and } \\
\text { arrange containers in } 10 \text { batches of } 100 \\
\text { paper money and } 2 \text { batches of } 500 .\end{array}$ \\
\hline
\end{tabular}

\subsection{Assessment of upper limb repetitive movements (OCRA Method).}

The job requires repetitive movements of the upper extremities in all jobs. Predominantly flexion and extension of the wrists, both elbows, neck flexion. Table 3 presents the results of the application of the OCRA method. Five jobs are only two of them have higher level of risk associated with repetitive motion. workday is 09 hours a day. They have 60 minutes for lunch and a break of 10 minutes in the afternoon when they change the security video. Also were observed 5 minutes breaks in the middle of the morning and one at the end of the day.

Table 3. Evaluation of repetitive movements of upper limbs per job. Transport company values. Venezuela. 2010.

\begin{tabular}{|l|l|l|}
\hline Workstation & index OCRA & $\begin{array}{l}\text { Risk Level } \\
\text { OCRA }\end{array}$ \\
\hline Vault Chief & 8,5 & Very light \\
\hline Opening remittances & 8,5 & Very light \\
\hline Assistant vault & 8,5 & Very light \\
\hline Paper Money selection & 12,75 & Light \\
\hline Financial remittances & 20,25 & Means \\
\hline
\end{tabular}

Source: Research data
Table 4. Evaluation of positions with RULA score and according to level of performance for each job. Values Transport company. Venezuela, 2010.

\begin{tabular}{|c|c|c|c|c|}
\hline \multirow[t]{2}{*}{ Workstation } & \multicolumn{4}{|c|}{ Valuation of postures } \\
\hline & $\begin{array}{l}\mathrm{N}^{\circ} \\
\text { observed } \\
\text { posture }\end{array}$ & Rating & Level & Performance \\
\hline \multirow{3}{*}{ Vault Chief } & \multirow{3}{*}{03} & 4 & 2 & change the task \\
\hline & & 4 & 2 & change the task \\
\hline & & 2 & 1 & Acceptable \\
\hline \multirow{3}{*}{$\begin{array}{l}\text { Opening } \\
\text { remittances }\end{array}$} & \multirow{3}{*}{03} & 2 & 1 & Acceptable \\
\hline & & 2 & 1 & Acceptable \\
\hline & & 2 & 1 & Acceptable \\
\hline \multirow{2}{*}{$\begin{array}{l}\text { Assistant } \\
\text { vault }\end{array}$} & 02 & 2 & 1 & Acceptable \\
\hline & & 2 & 1 & Acceptable \\
\hline \multirow{2}{*}{$\begin{array}{l}\text { Paper Money } \\
\text { selection }\end{array}$} & 02 & 2 & 1 & Acceptable \\
\hline & & 4 & 2 & change the task \\
\hline \multirow{5}{*}{$\begin{array}{l}\text { Financial } \\
\text { remittances }\end{array}$} & \multirow{5}{*}{05} & 3 & 2 & change the task \\
\hline & & 4 & 2 & change the task \\
\hline & & 6 & 3 & $\begin{array}{l}\text { redesign of the } \\
\text { task }\end{array}$ \\
\hline & & 4 & 2 & change the task \\
\hline & & 3 & 2 & change the task \\
\hline
\end{tabular}

Table 4. features 15 variations of postures observed in the five work stations. The workstation financial remittances received the highest score in the RULA assessment, ranging from 3 to 6 points, for a 2 to 3 level of risk. These workers alternate between sitting and standing posture with the trunk in flexion and performing repetitive movement of the upper limb, elbow flexion and extension and pincer grip. During the organization of remittances the weights manipulated most frequently was $11 \mathrm{~kg}$.

In the workstation selection of paper money, predominantly upright posture and result OCRA index 12.75 (low risk). The rest of the workstations reached OCRA index of 8.5 (very low risk). 


\section{Discussion}

The security transport companies require a high level of security for its customers, a situation that requires high demands and responsibility of their employees, requiring constant care and supervision as well as the physical demands.

This study confirmed the presence of the following risk factors that could explain the skeletal muscle disorders in upper limbs, shoulders and neck were as follows: the repetitive motion of flexion and extension of the wrist, shoulder elevation, lifting above height of the shoulders. Repetitive flexion and extension of elbow, neck flexion and stress due to the work requirements.

Finally, the root cause is due to the organization of work (long hours), short rest, work-overload, mental demand, high responsibility and having to work under strict supervision by a video camera.

\section{References}

[1] Colombini, D., Occhipinti, E. \& Grieco, A. (2000). OCRA. A check-list model for the quick evaluation of risk exposure (ocra index). Extraído el 8 de Septiembre de 2010. Disponible en: http:// www.ergonautas.upb.es/metodos/ocra/ocra-ayuda.php

[2] Escalona E, Yonnusg M, González R, Chatygny C, Seifert AM (2002). LA ERGONOMIA COMO HERRAMIENTA PARA TRABAJADORAS Y TRABAJADORES. 1ra Ed. Valencia: Ediciones Universidad de Carabobo

[3]. Guérin, F., Laville, A., Daniellou, F., \& al, e. (1991). Comprende le travail pour le transformer la practique de l'ergonomie. Francia: Ed. ANACT.

[4] Malchaire, J. (s/f) Unité Hygiéne et Physiologie du travail Prof. J. Malchaire SOBANE Deparis. Extraído el 03 de Mayo de 2009, de la siguiente dirección electrónica: http://www.Déparisnet.be/sobane/SOBANE.htm\#DéparisF R.

[5] McAtamney, L. \& Corlett, E.N. (1993). RULA: Un método de encuesta para la Investigación de los transtornos de las extremidades superiores relacionados con el trabajo. Applied Ergonomics, 24, 91-99. 